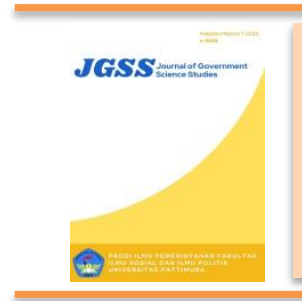

Journal of Government Science Studies

Available online at https://ojs3.unpatti.ac.id/

Vol. 1 No. 1, April 2022, pages: 09-17

e-ISSN: 2827-847X, p-ISSN: 2827-8461

https://doi.org/10.53730

\title{
Peran Lembaga Adat dan Pengaruhnya Terhadap Pelaksanaan Pembangunan di desa Batu Merah Kota Ambon
}

\author{
Haris Bin Haji ${ }^{\text {a }}$ \\ Corespondensi Author e-mail: haris.alaska@gmail.com
}

Manuscript submitted: 28-01-2022, Manuscript revised: 31-01-2022, Accepted for publication: 01-02-2022

Kata Kunci:
Lembaga Adat 1;
Pelaksanaan
pembangunan 2;
Pemerintahan adat 3;
Relasi kekuasaan 4.

\begin{abstract}
Abstrak: Penelitian yang dilakukan untuk melakukan analisis pengaruh peran lembaga adat dalam pelaksanaan pembangunan di Desa Batu Merah Kota Ambon. Lemahnya peran lembaga-lembaga adat di Maluku dalam memberikan kontribusi gagasan belum dirasakan sebagai lembaga yang memiliki kekuataan kekuasaan sebagai penyeimbang pemerintah adat. Permasalahan tersebut sehingga saat menarik untuk melakukan studi pemerintahan adat sebagai bagian sistem pemerintah desa. Metode penelitian yang digunakan dalam penelitian ini yaitu deskriptif kuantitaif dengan membagi pertayaan penelitian kepada informan kunci untuk mengetahui seberapa pengaruh lembaga adat dalam melakukan perencanaan pembangunanan. Hasil penelitian (1). Hipitesis Nihil (Ho) yaitu tidak ada hubungan yang signifikan antara Peran Lembaga Adat Dengan Penyelenggaraan Pembangunan Desa di Desa Batu Merah Kecamatan Sirimau Kota Ambon. (2). Hipotesis Alternatif (Ha) yaitu ada hubungan yang signifikan Peran Lembaga Adat Dengan Penyelenggaraan Pembangunan Desa di Desa Batu Merah Kecamatan Sirimau Kota Ambon. Sehingga tidak ada hubungan yang sangat signifikan peran lembaga adat dalam perencanaan pembangunan namun di pengaruh oleh faktor lain.
\end{abstract}

\footnotetext{
a Sekolah Tinggi Ilmu Administrasi
} Abdulazis Kataloka, Indonesia

Haji, B, H. (2021). Pengaruh Lembaga Adat dan Pengaruhnya Terhadap Pelaksanan Pembangunan Desa Batu Merah Kota Ambon. (Journal of Government Science Studies), 1(1). 


\section{Pendahuluan}

Menyangkut lembaga adat di Negeri Amahusu tidak dapat dilepaskan pisahkan dengan sikap Lembaga Adat yang berupaya menjalankan tugas Negeri. Lembaga adat dalam konteks ini adalah sebagai Lembaga yang ditunjuk untuk mengawasi jalannya pemerintahan negeri, serta hal-hal lain yang berhubungan dengan teknik musyawarah Pandangan tentang Lembaga sosial masyarakat sebagaimana Durkhein (Johnson, Paul Doyle, 1986), bahwa keberadaan Lembaga adat Saniri dalam fungsi pembagian kerja pada masyarakat tradisional organic memberikan kontribusi besar mengenai fungsi dan peranan anggota masyaralkat dan fungsionaris adat dalam meningkatkan integritas sosial. Menurut Emil salim (1999) dijelaskan bahwa proses pembangunan termasuk pengelolaan lingkungan hidup yang berlangsung dalam suatu kawasan adat harus memperhatikan hukum adat atau norma-norma lama yang berkembang di dalam masyarakat, karena hukum adat merupakan mekanisme kontrol bagi perilaku dan tindakan manusia (Salim, 1999).

Kinerja Lembaga adat mulai menjadi perhatian utama pemerintah dalam hal ini pemerintah daerah sebagai unit pelaksana teknis di daerah ketika otonomi daerah direalisasikan, sebagaimana amanat Undang-Undang Nomor 32 Tahun 2004 tentang pemerintah Daerah. Telah memberikan isyarat secara tegas untuk mengakomodasi kearifan lokal yaitu didalamnya terdapat pengakuan atas peraturan desa dalam hirakhi perundang-undang nasional. Paradigma baru administrasi publik muncul dengan merumuskan serangkaian idealism dan praktik terkait penggunaan nilai dan norma tertentu dalam pelaksanaan akuntabilitas pelayanan publik (Herizal, Mukhrijal, Wance, 2020).

Pengakomodasian ini otomatis memberdayakan Lembaga adat yang keberadaanya telah lama bersama masyarakat yang bersangkutan. Sehingga dalam proses kebijakan publik oleh pemerintah yang harus merangkul unsur masyarakat, tentu saja bukan merupakan hal yang sulit bagi pemerintah, sebab fungsionaris adat dapat memberikan informasi mengenai tata dan struktur masyarakat yang dipimpinya sebagai data base bagi pemerintah dalam merumuskan kebijakan publik.

Hal ini berarti bahwa dalam lingkup pemerintahan, pengelolaan dan pemanfaatan sumber daya alam dan sumber daya manusia sebagai sumber pendapatan desa maupun pola manajemen pembangunan desa, dimana skala prioritasnya mengacu pada fisik desa dan sikap mental masyarakat. (G. Kartasaputra, dkk, 1986). Sehingga pada konteks ini, maka keharmonisan dan keserasian kerja antar aparat baik struktur maupun fungsional yang ada di desa mutlak diperlukan demi lancarnya proses pembangunan di desa. Ada empat alasan pelaksaan otonomi daerah yaitu (1). Birokrasi yang rumit. (2). Representasi kelompok elit di daerah. (3). Struktur pemerintahan. (4). Desentralisasi kewenangan (Syaukani, dkk, 200). Pelaksanaan program dilakukan melalui dua tahapan yaitu persiapan dan pelaksanaan (Wance, Muhtar, Kaliky, 2020).

Konsep keserasian dan keharmonisan dalam hubungan antar lembaga ini harus diperhatikan karena seringkali ditemui bahwa banyak kasus yang terjadi di desa juga disebabkan oleh adanya perbedaan interpretasi antar unsur pemerintahan desa dengan lembaga adat. Perbedaan interpretasi ini terkadang berimbas pada perbedaan kebijakan dan sikap sehingga menimbulkan dualisme keputusan yang berdampak pada terjadinya perpecahan dalam masyarakat. Menghambat munculnya kekuatan-kekuatan perubahan dalam masyarakat (Tjokroaminoto, 1990). Kelembagaan lokal menurut Soejono Sukanto (1994) mempunyai tiga fungsi yaitu (a). Meningkatkan kapasitas sosial (social capacity) untuk melakukan tindakan yang terkoordinasi. (b). Membolehkan individu berintegrasi secara reguler diantara anggota dan memberdayakan (empower) individu sebagai pelaku aktivitas pembangunan. (c). Menyediakan struktur yang stabil untuk bertindak dalam mencapai tujuan kelompok. Selanjutnya menurut Zuraida dan J. Rizal (1993) adat adalah suatu sistem nilai-nilai dan kaidah-kaidah sosial yang tumbuh bersama-sama dengan tumbuhnya pengalaman hidup suatu masyarakat dan sebagai salah satu unsur utama kebudayaan yang berakar kuat dalam tata hidupnya 
Pelaksanaan implementasi otonomi daerah, idealnya lembaga adat dapat memiliki kontribusi sebagai komponen masyarakat yang ada di daerah. Peranan di sini dimaksudkan adalah tentang perihal apa yang dapat dilakukan Lembaga Adat dalam masyarakat sebagai organisasi kemasyarakatan. Lembaga adat berkedudukan sebagai wadah organisasi permusyawaratan/permufakatan para pengurus adat, pemuka-pemuka adat/masyarakat yang berada di luar susunan organisasi pemerintahan. Adapun tugas lembaga adat, berikut ini penulis kutip rumusan dari Peraturan Menteri dalam Negeri (Permendagri) Nomor 3 Tahun 1997 sebagai berikut:

a). Menampung dan menyalurkan pendapat masyarakat kepada pemerintah serta menyelesaikan perselisihan yang menyangkut hukum adat, adat istiadat dan kebiasaan-kebiasaan masyarakat.

b). Memberdayakan, melestarikan, dan mengembangkan adat istiadat dan kebiasaan-kebiasaan masyarakat dalam rangka memperkaya budaya daerah serta memberdayakan masyarakat dalam menunjang penyelenggaraan pemerintahan, pelaksanaan pembangunan, dan pembinaan kemasyarakatan.

c). Menciptakan hubungan yang demokratis dan harmonis serta objektif antara kepala adat/pemangku adat/tetua adat dan pimpinan atau pemuka adat dengan aparat pemerintah di daerah

Bertolak dari pemikiran ini, maka untuk mengetahui kenapa sampai di Negeri Amahusu lembaga adat telah mengalami suatu degradasi yang sangat kuat, serta adanya kecemasan akan hilang walaupun adanya proses penguatan dari pada pemerintah Propinsi Maluku (Pemprov) yang telah mengeluarkan perda payung Peraturan Daerah (Perda) Nomor 14 tahun 2005 Tentang Penetapan Kembali Negeri Sebagai Kesatuan Masyarakat Hukum Adat Dalam Wilayah Propinsi Maluku. Bertolak dari Peraturan Daerah (Perda) payung tersebut maka hampir kota dan kabupaten telah mengakomudirnya serta memberi peluang bagi Lembaga atau Negeri Adat itu kembali eksis. Sejalan dengan itu Soejono Soekanto (1989) mengemukakan bahwa lembaga adat dibentuk untuk mengelola pemberlakuan hukum adat terutama menyangkut hak-hak atas tanah.

Khususnya di daerah Maluku, sistem pemerintahan tradisional merupakan nilai budaya yang luhur dan beradab serta dapat digunakan untuk menyukseskan pembangunan. Konsep ini sejalan dengan apa yang dikemukakan oleh Budikusuma (1992) bahwa masyarakat Maluku mempunyai beberapa organisasi adat yang amat cocok digunakan dalam pembangunan.

Di Kota Ambon Kecamatan Nusaniwe tepatnya pada Desa Amahusu ditemukan gejala-gejala yang masih kuatnya nilai adat dalam penyelenggaraan pemerintahan desa, diantaranya:

1. Proses pemilihan kepala desa harus mendapat persetujuan dari marga yang merupakan mata rumah raja yang biasa dikenal dengan soa perintah (Silooy)

2. Penyelenggaraan keputusan desa harus dilakukan kerjasama dengan lembaga adat.

3. Merumuskan peraturan desa lembaga adat turut diikutsertakan.

4. Pelantikan Kepala Desa atau Raja oleh Walikota belum resmi apabila belum dilantik secara adat.

Pelaksanaan tata kelola Desa Amahusu sebagai salah satu desa adat bila ditinjau dari aspek pemerintahan maka dijumpai dua kategori pemerintahan yaitu aparat pemerintahan desa yang merupakan lembaga formal dan lembaga adat sebagai lembaga informal di desa. Untuk itu keberadaan kedua lembaga ini di Desa Amahusu menarik untuk dikaji dan diteliti terutama menyangkut hubungan antar kedua lembaga ini dalam mengatur rodan pembangunan dan mengatasi berbagai permasalahan dalam pembangunan di Desa Amahusu.

Mekanisme ini Pemerintahan Nasional melimpahkan kewenangan kepada pemerintahan dan masyarakat setempat atau lokal untuk diselenggarakan untuk meningkatkan kesejahteraan masyarakat. Dengan demikan desentralisasi akan membawa sejumlah manfaat bagi masyarakat lokal dan juga pemerintahan nasional. Menurut Cheema dan Rondinelli ( dalam Syaukani, dkk, 
2000), paling tidak terdapat empat (4) alasan yang merupakan rasionalitas dari desentralisasi dari empat belas (14) alasan yang dikutip disini adalah sebagai berikut ;

1. Desentralisasi dapat memotong jalur birokasi yang rumit serta prosedur yang sangat terstruktur dari pemerintah pusat.

2. Desentralisasi memungkinkan representasi yang lebih luas dari berbagai kelompok politik, etnis, keagamaan di dalam perencanaan pembangunan yang kemudian dapat memperluas kesamaan dalam mengalokasikan sumber daya dan investasi pemerintah.

3. Struktur pemerintah yang didesentralisasikan diperlukan guna melembagakan partisipasi masyarakat dalam perencanaan dan implementasi program.

4. Desentralisasi dapat menghantarkan kepada administrasi pemerintah yang mudah disesuaikan, inovatif, dan kreatif. Pemerintah daerah dapat memiliki peluang untuk menguji inovasi, serta bereksperimen dengan kebijaksanaan yang baru di daerah-daerah tertentu tanpa harus menjaustifikasinya kepada seluruh wilayah negara.

Selanjutnya The Liang Gie (1986) menyebutkan alasan dilaksanakannya desentralisasi dalam penyelenggaraan pemerintahan di Indonesia , adalah ;

1. Alasan kulturil, perbedan-perbedaan dalam berbagai faktor di seluruh Indonesia mudah meletus menjadi perasaan tidak puas terhadap Pemerintah Pusat apalagi diatur secara seragam dari atas. Oleh karena itu perlu diselenggarakan pemerintahan daerah untuk secara bebas dan sendiri-sendiri mengatur perbedaan-perbedaan di daerahnya.

2. Alasan kesadaran bernegara dan pembangunan ekonomi. Dengan adanya pemerintahpemerintah daerah yang dekat dan langsung dapat dilihat oleh rakyat, maka mereka (rakyat) akan merasa mempunyai suatu negara dan pemerintah yang tindakan-tindakannya dapat mereka rasakan secara langsung.

\section{Metode Penelitian}

Meteode penelitian adalah deskriptif kuantitatif dengan membagi pertyaan penelitian kepada informan yang dipilih. Menjadi populasi dalam penelitian ini adalah seluruh anggota Saniri yang berjumlah 18 orang dan unsur Aparatur Pemerintah Desa Amahusu Kecamatan Nusaniwe Kota Ambon yang berjumlah 8 orang, serta unsur masyarakat dalam desa Induk Amahusu yang telah berumah tangga sebanyak 512 orang.

Mengingat jumlah populasi dari unsur anggota lembaga Saniri dan unsur aparat pemerintah desa dapat dijangkau maka penarikan sampel dalam penelitian ini akan ditarik secara sensus. Untuk ini sample dari unsur ini seluruhnya berjumlah 26 orang. Sedangkan penarikan sample dari unsur Kepala Keluarga akan dilakukan dengan teknik random sampling dengan menggunakan prosentase sebesar $5 \%$ sehingga diperoleh sebanyak 512 orang, diperoleh 26 orang. Sehingga, dengan demikian jumlah sample penelitian ini secara keseluruhan berjumlah 52 orang.

\section{Hasil dan Diskusi}

Berdasarkan pedoman penggunaan rumus tersebut, setelah didefenisikan secara operasional kedalam daftar pertanyaannya masing dan setelah diuji pada sejumlah responden, berikut ini akan penulis sampaikan distribusi jawaban responden terkait dengan indikator-indikator variabel Peran Lembaga adat (Saniri) sebagai variabel pengaruh/variabel bebas (Variabel X) yang ada dapat dilihat pada tabel berikut ini: 
Tabel 1

Jawaban Responden Dalam Variabel X Peran Lembaga adat (Saniri)

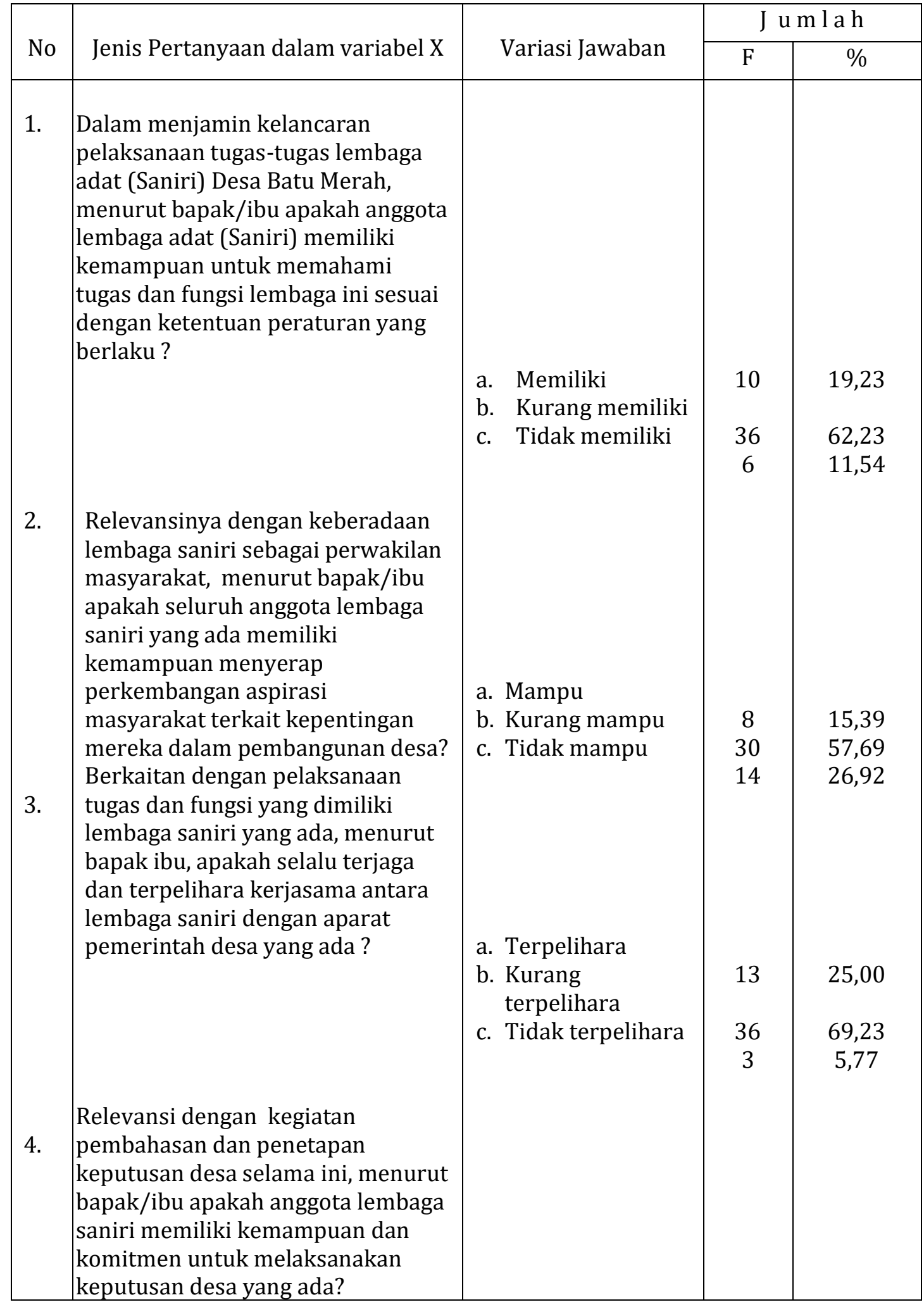

Haji, B, H. (2021). Pengaruh Lembaga Adat dan Pengaruhnya Terhadap Pelaksanan Pembangunan Desa Batu Merah Kota Ambon. (Journal of Government Science Studies), 1(1). 


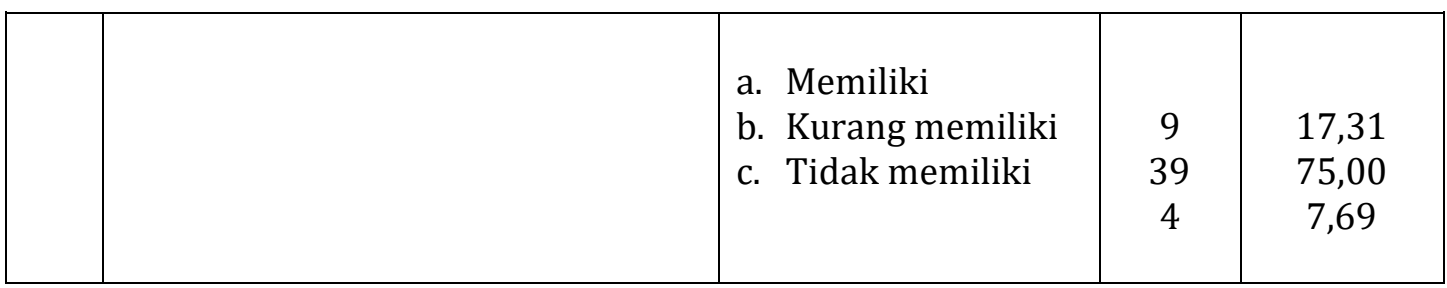

\section{Sumber: Analisis data penelitian}

Dari data dalam tabel diatas menunjukan bahwa kecenderungan jawaban responden adalah sebagai berikut:

1. Sebanyak 10 orang $(19,23 \%)$ mengatakan bahwa anggota lembaga adat (Saniri) memiliki kemampuan untuk memahami tugas dan fungsi lembaga ini sesuai dengan ketentuan peraturan yang berlaku dalam menjamin kelancaran pelaksanaan tugas-tugas lembaga adat (Saniri) Desa Batu Merah, dan sebanyak 36 orang (62,23 \%) mengatakan kurang memiliki, sedangkan sebanyak 6 orang lainnya (11,54 \%) mengatakan bahwa anggota lembaga adat (Saniri) tidak memiliki kemampuan kearah tersebut.

2. Relevansi dengan pertanyaan apakah seluruh anggota lembaga saniri yang ada memiliki kemampuan menyerap perkembangan aspirasi masyarakat terkait kepentingan mereka dalam pembangunan desa, terlihat sebanyak 8 orang $(15,39 \%)$ mengatakan mampu, dan sebanyak 30 orang (57,69 \%) mengatakan kurang mampu, serta sisanya sebanyak 14 orang lainnya $(26,92 \%)$ mengatakan tidak mampu.

3. Berkaitan dengan pertanyaan tentang apakah tentang pelaksanaan tugas dan fungsi yang dimiliki lembaga saniri yang ada, apakah selalu terjaga dan terpelihara kerjasama antara lembaga saniri dengan aparat pemerintah desa yang ada ?, terlihat sebanyak 13 orang (25 \%) mengatakan terpelihara, dan sebanyak 36 orang (69,23 \%) mengatakan kurang terpelihara, serta sisanya sebanyak 3 orang lainnya (5,77 \%) mengatakan tidak terpelihara.

4. Pada pertanyaan terakhir tentang apakah anggota lembaga saniri memiliki kemampuan dan komitmen untuk melaksanakan keputusan desa yang ada, menunjukkan bahwa sebanyak 9 orang $(17,31 \%)$ mengatakan memiliki, dan sebanyak 39 orang $(75 \%)$ mengatakan kurang memiliki serta sisanya sebanyak 4 orang $(7,69 \%)$ mengatakan tidak memiliki.

Selanjutnya, untuk mengetahui tanggapan responden terkait dengan pertanyaan-pertanyaan yang diajukan dalam variabel terikat (Variabel Y) atau variabel pentelenggaraan Pembangunan Desa, dapat diikuti secara rinci pada tabel di bawah ini

Tabel 2

Jawaban Responden Dalam Variabel Penyelenggaraan Pembangunan Desa

\begin{tabular}{|l|l|c|c|c|}
\hline \multirow{2}{*}{ No } & Jenis Pertanyaan dalam variabel Y & Variasi Jawaban & \multicolumn{2}{|c|}{ J u m l a h } \\
\cline { 3 - 4 } 1. & $\begin{array}{l}\text { Menurut bapak/ibu apakah anggota } \\
\text { Lembaga Adat dalam hal ini Saniri } \\
\begin{array}{l}\text { Negeri yang ada, selalu aktif } \\
\text { mengikuti pelaksanaan rapat-rapat } \\
\text { desa terkait penyusunan rencana } \\
\text { pembangunan desa yang } \\
\text { diselenggarakan oleh pemerintah }\end{array}\end{array}$ & & \\
\hline
\end{tabular}




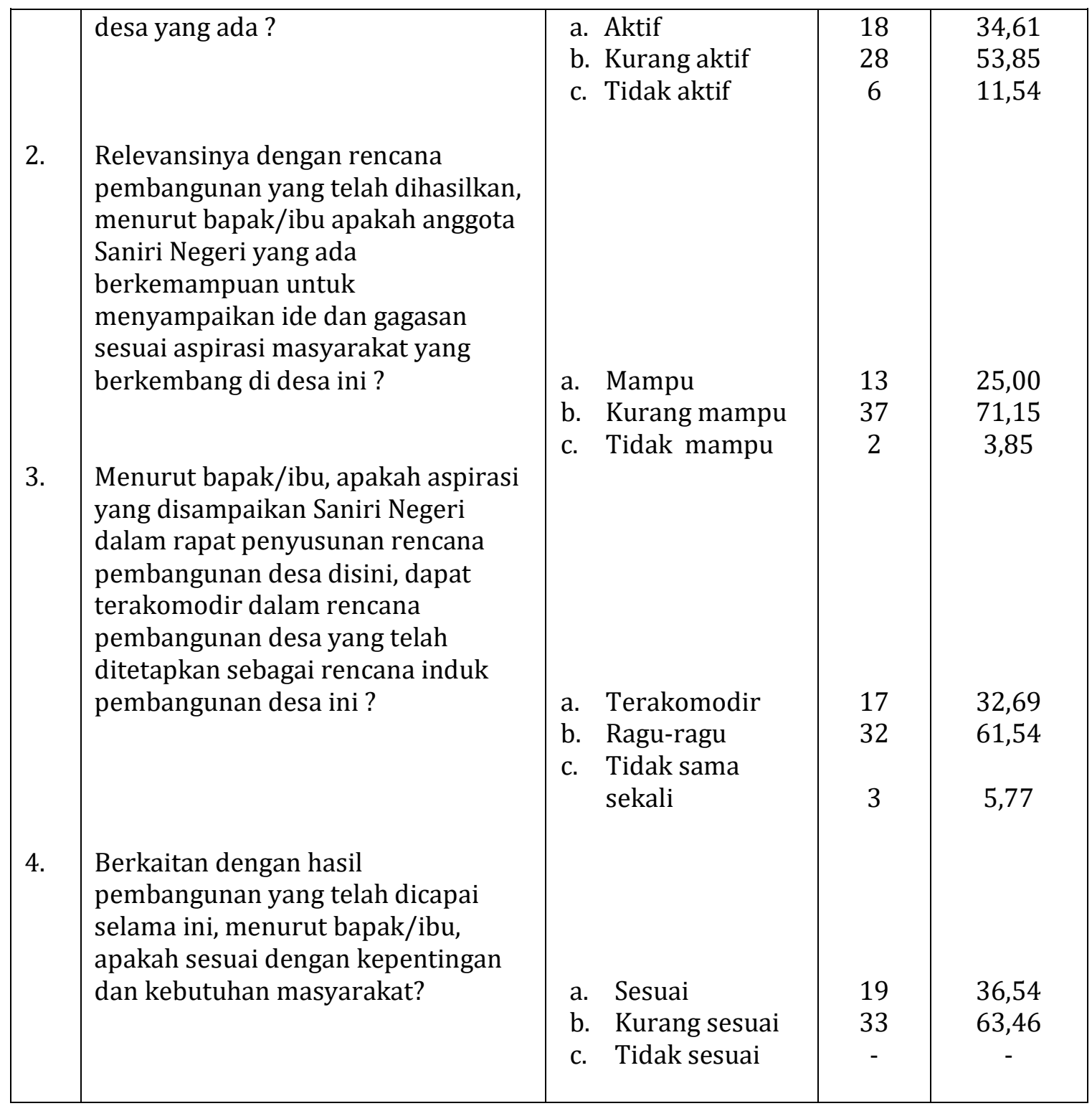

\section{Sumber: Analisis data penelitian}

Dari data dalam tabel diatas menunjukan bahwa kecenderungan jawaban responden adalah sebagai berikut:

1. Dalam kaitannya pertanyaan tentang anggota Lembaga Adat dalam hal ini Saniri Negeri yang ada, selalu aktif mengikuti pelaksanaan rapat-rapat desa terkait penyusunan rencana pembangunan desa yang diselenggarakan oleh pemerintah desa yang ada, memperlihatkan sebanyak 18 orang atau (34,61\%) menyatakan aktif, dan sebanyak 28 orang atau $(53,85 \%)$ menjawab kurang aktif terhadap hal tersebut serta sebanyak 6 orang $(11,54 \%)$ menjawab tidak aktif sama sekali.

2. Dari pertanyaan kedua tentang apakah anggota Saniri Negeri yang ada berkemampuan untuk menyampaikan ide dan gagasan sesuai aspirasi masyarakat yang berkembang di desa ini, menunjukkan sebanyak 13 orang (25 \%) menjawab bahwa anggota Saniri Negeri yang ada berkemampuan untuk menyampaikan ide dan gagasan sesuai aspirasi 
masyarakat yang berkembang di desa ini, dan sebanyak 37 orang $(71,15 \%)$ menjawab kurang mampu serta sisanya sebanyak 2 orang atau (3,85 \%) menjawab tidak mampu.

3. Dalam kaitannya dengan pertanyaan tentang apakah aspirasi yang disampaikan Saniri Negeri dalam rapat penyusunan rencana pembangunan desa disini, dapat terakomodir dalam rencana pembangunan desa yang telah ditetapkan sebagai rencana induk pembangunan desa ini, menunjukkan sebanyak 17 orang (32,69 \%) mengatakan terakomodir, dan sebanyak 32 orang (61,54\%) mengatakan ragu-ragu tentang hal ini, serta sebanyak 3 orang lainnya (5,77\%) mengatakan tidak sama sekali.

4. Pada bagian lain memperlihatkan bahwa sebanyak 19 orang atau $(36,54 \%)$ menyatakan bahwa hasil pembangunan yang telah dicapai selama ini di Desa batu Merah, sesuai dengan kepentingan dan kebutuhan masyarakat, sedangkan sebanyak 33 orang lainnya $(63,46 \%)$ menjawab kurang sesuai dengan kepentingan dan kebutuhan masyarakat.

\section{Kesimpulan}

Adapun yang menjadi masalah pokok dalam penelitian ini adalah Apakah ada hubungan yang positif antara Peran Badan Permusyawaratan Desa (BPD) dengan Partisipasi Masyarakat Dalam Pembangunan Desa di Desa Batu Merah Kecamatan Sirimau Kota Ambon?. Untuk menjawab permasalahan pokok tersebut di atas, diajukan dua hipotesis yang terdiri dari :

- Hipitesis Nihil (Ho) yaitu "Tidak ada hubungan yang signifikan antara Peran Lembaga Adat Dengan Penyelenggaraan Pembangunan Desa di Desa Batu Merah Kecamatan Sirimau Kota Ambon".

- Hipotesis Alternatif (Ha) yaitu "Ada hubungan yang signifikan Peran Lembaga Adat Dengan Penyelenggaraan Pembangunan Desa di Desa Batu Merah Kecamatan Sirimau Kota Ambon".

Dari hasil perhitungan memperlihatkan bahwa nilai r korelasi yang diperoleh sebesar 0,707, nilai ini setelah dibandingkan dengan standart pedoman di depan, maka nilai korelasi 0,707 pada posisi interval ( 0,70 - 0,799) yang berarti bahwa korelasi yang terjadi bersifat positif tetapi berada pada tingkat hubungan yang Kuat antara Peran Lembaga Adat (Saniri) dengan Penyelenggaraan Pembangunan Desa di Desa Batu Merah Kecamatan Sirimau Kota Ambon.

\section{Referensi}

D. Zuraida dan J. Rizal. (1993). Masyarakat dan Manusia dalam Pembangunan. Pokok-pokok Pikiran Selo Soemardjan, Pustaka Sinar Harapan, Jakarta.

G. Kartasaputra; dkk. (1986). Desa dan Peranan dan Tata Pemerintahannya, Bina Aksara, Jakarta.

Johnson, Doyle Paul (1988) Teori Sosiologi Klasik dan Modern Jilid I. Diindonesiakan oleh Robert MZ Lawang, PT Gramedia: Jakarta

Herizal, H., Mukhrijal, M., \& Wance, M. (2020). Pendekatan akuntabilitas pelayanan publik dalam mengikuti perubahan paradigma baru administrasi publik. Journal of Governance and Social Policy, 1(1).

Hilman Budikusuma. 1992). Pengantar Ilmu Hukum Adat di Indonesia, Mandar Maju

Salim, Emil. (1999). Opini Masyarakat dari Krisis ke Reformasi, Demokratisasi dan Otonomi Mencengah Disintegrasi Bangsa, Jakarta, Kompas.

Soejono Sukanto. (1994). Pengantar Penelitian Hukum, Universita Indonesia 
Syaukani, dkk. (2000). Otonomi Daerah dalam Negara Kesatuan, Yogyakarta, Kerja sama Pustaka Pelajar dan Pusat dan Pengkajian Etika Politik dan Pemerintahan.

Tjokroaminoto Moelijarto. (1989). Pembangunan Negara Berkembang, Aplikasi, Praktek dan Teori, PPs - UGM, Jogjakarta.

The Liang Gie. (1986). Pertumbuhan Pemerintahan Daerah di Negara Republik Indonesia, Jilid III, Jakarta, Rajawali Press.

Wance, M., Muhtar, M., \& Kaliky, P. I. (2020). PKM Penyelenggaraan Pemerintahan Dalam Perencanaan Pembangunan Negeri Hila Kabupaten Maluku Tengah. CARADDE: Jurnal Pengabdian Kepada Masyarakat, 2(2), 229-338. 